\title{
IMPORTANCE OF COLLABORATION WITH EMPLOYERS TOWARDS THE RANKINGS OF HIGHER EDUCATION INSTITUTIONS
}

\author{
Evija Rusite ${ }^{1}$, Mg.biol., Mg.sc.admin./doctoral student; Biruta Sloka², Dr.oec./Professor \\ 1,2 University of Latvia
}

\begin{abstract}
It is impossible for higher education institutions (HEI) to ignore different national and international comparisons, since emergence of global rankings. Involvement in rankings changes and in some aspects improves the performance of higher education institutions. Trying to rise their position in the rankings, HEI are seeking ways, how to improve performance in those areas that are measured by the indicators used for rankings of HEI. The purpose of this study is to search for some possible solutions for more effective research work organization at the universities and correct reflection of achieved results to raise their position in university rankings.

Research methods used: analysis of scientific publications on university rankings aspects related to different methodologies and indicators; expert survey on university organisation and used ranking indicators. For expert interviews were invited internationally recognized university management representatives and several administrators at universities in different countries. For different aspect evaluations, there was used evaluation scale 1-10, where 1- do not agree and 10 - fully agree. Expert evaluations were analysed by descriptive statistics indicators and cross-tabulations.

Main results and findings: rankings have significant role in the development of HEI. It is important to define the accessible rankings position in the strategy of HEI. Higher education institutions must determine such goals and results of performance that favour the higher ranking position. For increase of international recognition HEI have to recognise that as well important aspects are the academic and employer reputation surveys in rankings.
\end{abstract}

Key words: university rankings, performance indicators, employers, experts.

JEL code: I23; O30; 032.

\section{Introduction}

It is impossible for higher education institutions (HEI) to ignore different national and international comparisons, since emergence of global rankings. This influences the way, how higher education institutions function and are planning their development. Involvement in rankings changes and in some aspects improves the performance of higher education institutions. Trying to rise their position in the rankings, higher education institutions are seeking ways, how to improve performance in those areas that are measured by the indicators used for rankings of higher education institutions. However, the question is whether devoting by HEI too big attention to the highest ranking positions causes the defining of incorrect priorities of the higher education institutions development and restricts the ensuring of the main activities of the respective HEI.

Many international academic research and investigations have been performed in this field, and the research results usually are used for management decision making on different levels: on university level, on higher education and science management level and on country management level.

Taking into account the above mentioned and extent how essential role ratings have in the forming of the reputation of higher education institutions, the purpose of this study is to search for some possible solutions for more effective research work organization at the universities and correct reflection of achieved results to raise their position in university rankings. Tasks: analyse scientific findings on university ranking aspects; compare scientific findings with international expert evaluation views.

Research methods used: analysis of scientific publications on university rankings aspects related to different methodologies, aspects in university rankings - research results, academic performance,

\footnotetext{
${ }^{1}$ Evija.Rusite@lu.Iv 
share of academic staff with their qualification levels, scientific citations and importance for employers and labour market development (even often discussed on their level of importance) and indicators; expert survey on university organisation and used ranking indicators aspects supporting university rankings. For expert interviews the authors invited internationally recognized university management representatives and several administrators at universities in different countries. For different aspect evaluations there was used evaluation scale 1-10, where 1- do not agree and 10 agree in full extent. Expert evaluations were analysed by descriptive statistics indicators - indicators of central tendency or location (arithmetic mean, mode, median) and indicators of variability or dispersion (range, standard deviation, standard error of mean) and cross-tabulations.

\section{Research results and discussion}

Theoretical findings in academic research are discussed in scientific community with often raised questions - is it possible to rank universities using fewer indicators? On this often stated question there is performed study on five international university rankings (Dogan, Al, 2019) - the purpose of Dogan and Al paper was to analyse the similarity of intra-indicators used in research-focused international university rankings (Academic Ranking of World Universities (ARWU), NTU University Rankings (NTU) - "Performance Ranking of Scientific Papers for World Universities" is released by National Taiwan University, and is also known as NTU Ranking. NTU Ranking provides overall ranking, rankings by six fields, and rankings by 14 selected subjects, University Rankings by Academic Performance (URAP), Quacquarelli Symonds (QS) and Round University Rankings (RUR)) over several years, and analyse the effect of similar indicators on overall rankings for 2015. The research questions of Dogan and Al research addressed in their study in accordance with these purposes were questions stated often also by other researchers: at what level are the intra-indicators used in international university rankings similar? Is it possible to group intra-indicators according to their similarities? What is the effect of similar intra-indicators on overall rankings? (Dogan G., Al U., 2019). Design/methodology/approach in Dogan and Al research paper was: indicator-based scores of all universities in five research-focused international university rankings. For data obtained in research Dogan and Al have used one of effective multivariate analysis methods for data analysis multidimensional scaling (MDS) and cosine similarity measure to analyse similarity of indicators and to answer these two research questions mentioned above. Indicator-based scores and overall ranking scores for 2015 were used as data and Spearman correlation test was applied by Dogan and Al to answer the third research question. Main findings of Dogan and Al: results of the analyses show that the intra-indicators used in ARWU, NTU and URAP are highly similar and that they can be grouped according to their similarities (Dogan G, Al U., 2019). Dogan and Al also have examined the effect of similar indicators on 2015 overall ranking lists for these three rankings. NTU and URAP are affected least from the omitted similar indicators, which means it is possible for these two rankings to create very similar overall ranking lists to the existing overall ranking using fewer indicators (Dogan $G, A l$ U., 2019).

Researchers are also interested in deeper academic studies on aspects - do the technical universities exhibit distinct behaviour in global university rankings? A Times Higher Education (THE) case study (Carmen P.-E., Enrique O.-M., 2018) where authors Carmen and Enrique have stressed that Technical Universities (TUs) exhibit a distinct ranking performance in comparison with other universities. In the mentioned paper, Carmen and Enrique have identified 137 TUs included in the Times Higher Education (THE) Ranking (2017 edition) and analysed their scores statistically. The research results of Carmen and Enrique highlighted the existence of clusters of TUs showing a general 
high performance in the Industry Income category and, in many cases, a low performance on Research and Teaching (Carmen P.-E., Enrique O.-M., 2018). Finally, the global score weights were simulated by Carmen and Enrique, creating several scenarios that confirmed that the majority of TUs (except those with a world-class status) would increase their final scores if industrial income was accounted for the levels parametrized (Carmen P.E., Enrique O.-M., 2018).

Very often stated question by researchers, policy makers and public administrators: Are university rankings useful to improve research? A systematic review was performed also by Balas and Momani where they have expressed their concerns about reproducibility and impact of research urge improvement initiatives (Balas A.E., Momani S., 2018). Balas and Momani have stressed that current university ranking systems evaluate and compare universities on measures of academic and research performance - those aspects are stressed by many other researchers. Balas and Momani have stressed that although often useful for marketing purposes, the value of ranking systems when examining quality and outcomes is unclear (Balas A.E., Momani S., 2018). The purpose of the Balas and Momani study was to evaluate usefulness of ranking systems and identify opportunities to support research quality and performance improvement. Balas and Momani study's methods are aimed at a systematic review of university ranking systems and the study was conducted to investigate research performance and academic quality measures (Balas A.E., Momani S., 2018).

Eligibility requirements included in Balas and Momani study: inclusion of at least 100 doctoral granting institutions, be currently produced on an ongoing basis and include both global and US universities, publish rank calculation methodology in English and independently calculate ranks. Ranking systems must also include some measures of research outcomes (Balas A.E., Momani S., 2018). Indicators in Balas and Momani study were abstracted and contrasted with basic study quality improvement requirements. Exploration of aggregation methods, validity of research and academic quality indicators, and suitability for quality improvement within ranking systems were also conducted in Balas and Momani study. Results of Balas and Momani study - total of 24 ranking systems were identified and 13 eligible ranking systems were evaluated (Balas A.E., Momani S., 2018). Six of the 13 rankings are $100 \%$ focused on research performance (Balas A.E., Momani S., 2018). Research results indicated that $76 \%$ of the total ranks are attributed to research indicators, with $24 \%$ attributed to academic or teaching quality (Balas A.E., Momani S., 2018). Seven university ranking systems rely on reputation surveys and/or faculty and alumni awards (Balas A.E., Momani S., 2018). Results of Balas and Momani study have indicated that university rankings influence academic choice (for students, for researchers and members of academic staff, for offers in conducting scientific research) and in most of research performance measures are the most weighted indicators for university rankings. There are No generally accepted academic quality indicators in ranking systems (Balas A.E., Momani S., 2018) and this is also one of reasons to have several university ranking systems applied world-wide. Discussion as a result of Balas and Momani study indicated that No single ranking system provides a comprehensive evaluation of research and academic quality. Utilizing a combined approach of the Leiden, Thomson Reuters Most Innovative Universities, and the SCImago ranking systems may provide institutions with a more effective feedback for research improvement (Balas A.E., Momani S., 2018). Rankings which extensively rely on subjective reputation and "luxury" indicators, such as award winning faculty or alumni who are high ranking executives, are not well suited for academic or research performance improvement initiatives (Balas A.E., Momani S., 2018). Balas and Momani study has stressed that future efforts should better explore measurement of the university research performance through comprehensive 
and standardized indicators. Balas and Momani study indicated that their research results could serve as a general literature citation when one or more of university ranking systems are used in efforts to improve academic prominence and research performance (Balas A.E., Momani S., 2018).

Although university rankings are performed internationally, in many countries academic research is conducted to analyse the influence of organisational features in high-ranked universities like in the case of Australia (Uslu B., 2017). Global university rankings influence more and more different aspects at universities and global university rankings are important for decision making on several levels: for student attraction, for organisation of academic work and research (Marginson S., 2007). International research results evaluations for global university rankings are stressed by several researchers (Saunders J., Wong V., 2011). Some other researchers for global university rankings stress student views importance in higher education organization (Sikosek M., Kodrioccarrojon B., 2011) and place of respective university in international university rankings (Williams R., Van Dyke N., 2007). Researchers have stressed the importance of obtained university rank in respective global university rankings (Sauder M., Espeland W.N., 2006).

Uslu research has examined the influence of major institutional components, academic support mechanisms and organisational climate on scholarly productivity in high-ranked universities. Qualitative research methods were applied to collect data. Data by researcher Uslu were collected from senior academics working in high-ranked Australian universities. The collected data were examined using thematic descriptive and content analysis techniques (Uslu B., 2017).

The results of Uslu research indicate that academic support practices help to save time by providing excelled knowledge related to new pedagogies and research preparation and by offering project management support. Results also show that a participatory work environment and fair institutional policies and practices generate intrinsic and extrinsic incentives to enhance academic role performance (Uslu B., 2017).

Often asked question is "on being good or being known" which is also related to university rankings (Rindova V.P., Williamson I.O., Petkova A.P., Sever J.M, 2005) and place of the university in several university rankings systems (Wæraas A., Solbakk M.N., 2009).

Those aspects are stressed also in other researchers' results and practical recommendations for policy decisions at universities and wider (O'Connell C., 2013). Uslu has stressed that to promote their institutional prestige, university managers should operate selective financial and human resource investment strategies as several university ranking systems are using several performance indicators in the evaluations of university performance.

To elevate the ranking of their institutions, they need to establish essential academic support structures and institute multi-directional communication networks with less bureaucracy, simplified hierarchical structures, effective reward systems, well-designed career planning and informative performance reviews (Uslu B., 2017).

Narrow places for university rankings are analysed in details and with strong approach, like finding seven deadly sins of world university ranking: a summary from several papers (Soh K., 2017). Attention to higher education rankings is paid also in developing countries, like Indonesia (Kusumastuti D., Idrus N., 2017) where the researchers indicate possible ways to make first steps for university rankings. Often used approach and asked question - does one size fits all? A different perspective on university rankings has indicated that importance of rankings is not going to reduce the importance (Goglio V., 2016) and how important are those results in research international recognition (Sombatsompop N. et al., 2011). 
University rankings as a tool for assessing the quality of education in the context of globalization is on research agenda for many researchers determining and designing policy directions for higher education quality improvement (Avralev N., Efimova I., 2015) and also aspects of university rankings and the reality (Williams R., Van Dyke N., 2008).

Several ranking systems' comparisons with clear question by researcher Soh specializing in university ranking research - „what the overall doesn't tell about world university rankings?” by examples from different university ranking systems: ARWU, QSWUR, and THEWUR conducted in 2013 (Soh K., 2015).

Researchers have paid attention to inconsistent year-to-year fluctuations limit in global higher education rankings for respective university management and researchers have suggested their findings for deeper use for university management and decision making (Sorz J., Wallner B., Seidler H., Fieder M., 2015). Researchers have analysed often asked questions on global university rankings correspondence to reality and respective consequences (Luca M., Smith J., 2013).

According to numerous international academic researchers, including researchers from University of Chickago Tutterow and Evans, university rankings and metrics have become an increasingly prominent basis of student decisions, generalized university reputation, and the resources universities attract for university activities (Tutterow C., Evans J.A., 2016.). Tutterow and Evans, have performed review of metrics used in rankings of higher education institutions about the influence of ranking on the position and strategic behavior of universities and students.

As it is mentioned in many scientific publications, also in Tutterow and Evans, most quantitative analyses on this topic estimate the influence of change in university rank on performance. University rankings are used to make different models for university competition (Grewal R., Dearden J.A., Lilien G.L., 2008). These studies consistently identify a small, short-lived influence of rank shift on selectivity (e.g., one rank position corresponds to around one percent more student applicants), comparable to ranking effects documented in other domains (Tutterow C., Evans J.A., 2016). Tutterow and Evans have stressed that this understates the larger system-level impact of metrification on universities, students, and the professions that surround them. Tutterow and Evans have explored one system-level transformation likely influenced by the rise of university rankings.

Recent years have witnessed the rise of student enrolment management and independent educational consultation. Researchers Tutterow and Evans have indicated conequences from university ranking to this transformation: in an effort to improve rankings, universities organise more applications from students to reduce student acceptance rate. Tutterow and Evans research results have proved that lower acceptance rates lead to more uncertainty for students about acceptance for studies, leading possible students to apply to more higher education institutions and those applications to severai HEI decrease the probability that accepted students will attend the respective university (Tutterow C., Evans J.A., 2016).

Alike conclusions are resulted also in other research results (Dill D.D., Soo M., 2005). As it is mentioned by Tutterow and Ecans - this leads to greater uncertainty about enrolment for students and universities and generates demand for new services to manage it. Reputation of higher education institution on international level motivates also marketing specialists to be involved in promotion of universities (Conard M.J., Conard M.A., 2000). Because these and other system-level transformations are not as cleanly measured as rank position and performance, they have not received the same treatment or modelling attention in higher education despite their importance for understanding and influencing education policy (Tutterow C., Evans J.A., 2016). Very often stated and analysed question 
by researchers in many countries are on academic research proportions and learning - teaching proportions at highly ranked universities (Jerrams S., Betts T., Carton J., 2008).

Globalisation of international comparisons and evaluation systems including global university rankings have been recently introduced as mechanisms for assessing overall academic quality, appraising research reputation and as a basis for funding and policy decisions (O'Loughlin D., MacPhail A., 2015).

Research results of researchers from Ireland O'Loughlin and MacPhail have confirmed that consistency of understanding of research reputation also exist among all users of ranking systems, particularly those involved in higher education policy and research strategy decision-making (O'Loughlin D., MacPhail A., 2015). This aspect is very important for university management but also for respective country higher education policy development.

University rankings are discussed more and more on international scientific conferences and meetings, developed in scientific publications to find reasonable arguments and include them for universities management decision making to prepare strategies of universities to make reasonable activities in priorities for universities act in their work and performance to reflect their achieved results of scientific and teaching achievements in respective university international university rankings.

In empirical part of research it was conducted expert survey for evaluation of the significance of the rankings of higher education institutions (HEI) - international experts of higher education were asked to evaluate the analysed aspects in scale 1 - 10, where 1 - fully disagree / absolute insignificant to 10 - fully agree / very significant. Main results of descriptive statistics of evaluations by international experts of higher education on the analysed aspects related to university rankings are included in Table 1.

Table 1

\section{Main indicators of descriptive statistics of international expert evaluations on higher education institutions rankings}

\begin{tabular}{|c|c|c|c|c|c|c|c|c|}
\hline & \multirow[b]{2}{*}{ 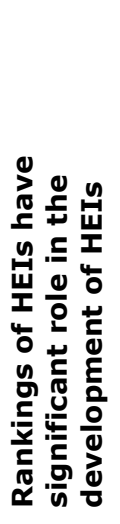 } & \multicolumn{3}{|c|}{$\begin{array}{l}\text { It is important to } \\
\text { define the accessible } \\
\text { rankings position in } \\
\text { the strategy of HEI }\end{array}$} & \multirow{2}{*}{ 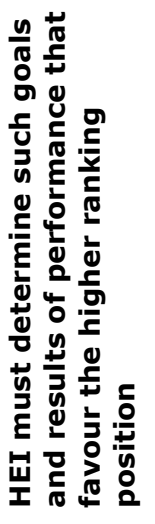 } & \multirow{2}{*}{ 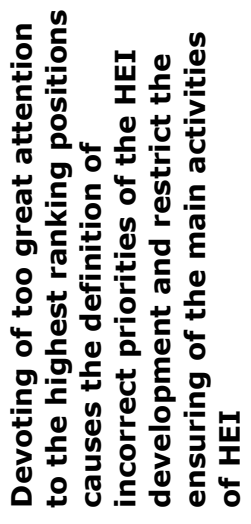 } & \multirow{2}{*}{ 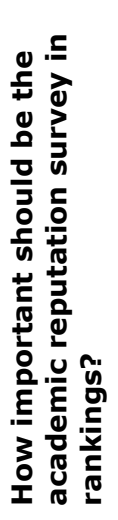 } & \multirow{2}{*}{ 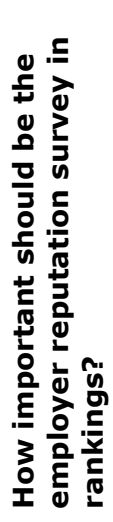 } \\
\hline & & 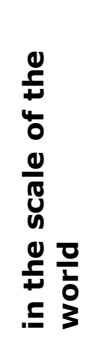 & 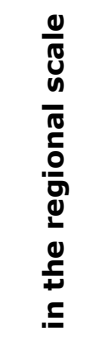 & 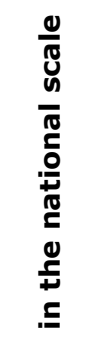 & & & & \\
\hline Mean & 5,57 & 6,00 & 5,29 & 6,43 & 5,29 & 8,00 & 3,71 & 3,43 \\
\hline $\begin{array}{l}\text { Std. Error of } \\
\text { Mean }\end{array}$ & 1,110 & 1,091 & 1,304 & 1,043 & 1,107 & 1,000 & 0,808 & 0,948 \\
\hline Median & 6 & 8 & 8 & 8 & 7 & 9 & 3 & 2 \\
\hline Mode & 8 & 8 & 8 & 8 & $7 ; 8$ & 10 & 3 & $1 ; 2$ \\
\hline Std. Deviation & 2,936 & 2,887 & 3,450 & 2,760 & 2,928 & 2,646 & 2,138 & 2,507 \\
\hline Variance & 8,619 & 8,333 & 11,905 & 7,619 & 8,571 & 7,000 & 4,571 & 6,286 \\
\hline Range & 7 & 7 & 7 & 8 & 7 & 7 & 6 & 6 \\
\hline Minimum & 1 & 1 & 1 & 1 & 1 & 3 & 1 & 1 \\
\hline Maximum & 8 & 8 & 8 & 9 & 8 & 10 & 7 & 7 \\
\hline
\end{tabular}

Evaluation scale 1 - 10, where 1 - fully disagree / absolute insignificant to 10 - fully agree / very significant

Source: author's calculations based on Evija Rusite conducted international expert survey, $n=7$; 
Data of Table 1 indicate that experts are on the opinion that "Devoting of too great attention to the highest ranking positions causes the definition of incorrect priorities of the HEI development and restrict the ensuring of the main activities of $\mathrm{HEI}^{\prime \prime}$ have the highest evaluations by experts with arithmetic mean 8, median 9 and mode 10 (in evaluation scale 1 - 10 with lowest given evaluation 3 by experts). Next higher evaluations by experts were for "It is important to define the accessible rankings position in the strategy of HEI in the national scale" with arithmetic mean 6,43, median 8 and mode 8; a little lower evaluations by experts were for "It is important to define the accessible rankings position in the strategy of HEI in the scale of the world".

Experts were very reserved in evaluations of aspect "How important should be the academic reputation survey in rankings?" with arithmetic mean 3,71, median 3 and mode 3 - for this analysed aspect experts had the lower differences in their evaluations as indicators of dispersion were the lowest, but the lowest evaluations were for the analysed aspect "How important should be the employer reputation survey in rankings?" with arithmetic mean 3,43, median 2 and mode 1 and 2 .

There were additional comments by experts „Reputation surveys are a just an indicator of how much a HEI „brand” is known (often for reason only historically linked to its quality) and including them in a university ranking perpetuates the same reputation over and over (the ranking in itself creates a reputation). Employers only know the graduated students they employ and it does not make sense to ask them which HEI produce the best ones (and the economy of the country the HEI is in, is the most relevant factor). Besides, existing academic surveys are not scientifically well built (regarding the questionnaire where they ask to name too many institutions and the population surveyed for subject and geographical areas covered in fact). They should be commissioned to a third party than the ranker." The comments are subjective attitude of experts but the survey was created in accordance of main aspects included in higher education rankings.

\section{Conclusions, proposals, recommendations}

1) Global university rankings have significant role in the development of higher education institutions. It is important to define the accessible rankings position in the strategy of higher education institution - in the scale of the world, in the regional scale and in the national scale. Higher education institutions must determine such goals and results of performance that favour the higher ranking position.

2) University rankings has increasing importance for attraction of students, for research financing competition results even if sometimes for university rankings is not paid enough attention by universities management.

3) International experts are on the opinion that "Devoting of too great attention to the highest ranking positions causes the definition of incorrect priorities of the HEI development and restrict the ensuring of the main activities of HEI" have the highest evaluations by experts - those findings could be taken into account by university management.

4) Experts of higher education have evaluated very low the importance of the academic reputation survey in rankings and the importance of the employer reputation survey in rankings.

5) Higher education institutions have to recognise that very important aspects are the academic and employer reputation surveys in university rankings. 


\section{Bibliography}

1. Avralev, N., Efimova, I. (2015). University rankings as a tool for assessing the quality of education in the context of globalization. Asian Social Science, Volume 11, Issue 10, pp. 292-298.

2. Balas, AE., Momani, S. (2018). Are university rankings useful to improve research? A systematic review. PLOS ONE, Volume 13, Issue 3, Article number e0193762.

3. Carmen, P.-E., Enrique, O.-M. (2018). Do the technical universities exhibit distinct behaviour in global university rankings? A Times Higher Education (THE) case study. Journal of Engineering and Technology Management, Volume 48, pp. 97-108.

4. Conard, M.J., Conard, M.A. (2000). An analysis of academic reputation as perceived by consumers of higher education. Journal of Marketing for Higher Education, Volume 9, Issue 4, pp. 69-80.

5. Dill, D.D., Soo, M. (2005). Academic quality, league tables, and public policy: A cross-national analysis of university ranking systems. Higher Education, Volume 49, Issue 4, pp. 495-533.

6. Dogan, G., Al, U. (2019). Is it possible to rank universities using fewer indicators? A study on five international university rankings, Aslib Journal of Information Management, Volume 71, Issue 1, pp. 18-37.

7. Goglio, V. (2016). One size fits all? A different perspective on university rankings. Journal of Higher Education Policy and Management, Volume 38, Issue 2, pp. 212-226.

8. Grewal, R., Dearden, J.A., Lilien, G.L (2008). The university rankings game: Modelling the competition among universities for ranking. American Statistician, Volume 62, Issue 3, pp. 232-237.

9. Jerrams, S., Betts, T., Carton, J. (2008). Building Sustainable Academic Research in a 'Teaching and Learning' Intensive Environment. Industry and Higher Education, Volume 22, Issue 3, pp. 189-194.

10. Kusumastuti, D., Idrus, N. (2017). Nurturing quality of higher education through national ranking: a potential empowerment model for developing countries. Quality in Higher Education, Volume 23, Issue 3, pp. 230-248.

11. Luca, M., Smith, J. (2013). Salience in Quality Disclosure: Evidence from the U.S. News College Rankings. Journal of Economics and Management Strategy, Volume 22, Issue 1, pp. 58-77.

12. Marginson, S. (2007). Global university rankings: Implications in general and for Australia. Journal of Higher Education Policy and Management, Volume 29, Issue 2, pp. 131-142.

13. O'Connell, C. (2013). Research discourses surrounding global university rankings: Exploring the relationship with policy and practice recommendations. Higher Education, Volume 65, Issue 6, pp. 709-723.

14. O'Loughlin, D., MacPhail, A. (2015). The rhetoric and reality of research reputation: 'fur coat and No knickers', Studies in Higher Education, Volume 40, Issue 5, pp. 806-820.

15. Rindova, V.P., Williamson, I.O., Petkova, A.P., Sever, J.M. (2005). Being good or being known: An empirical examination of the dimensions, antecedents, and consequences of organizational reputation. Academy of Management Journal, Volume 48, Issue 6, pp. 1033-1049.

16. Sauder, M., Espeland, W.N. (2006). Strength in numbers? The advantages of multiple rankings. Indiana Law Journal, Volume 81, Issue 1, pp. 205-227.

17. Saunders, J., Wong, V. (2011). Manoeuvring towards research decline: The RAE and the decline of Britain's international research standing. European Journal of Marketing, Volume 45, Issue 4, pp. 484-512.

18. Sikosek, M., Kodrioccarrojon, B. (2011). Student Expectations of higher education institution services in light of service differentiation. Management, Voulme 6, Issue 3, pp. 303-308.

19. Soh, K. (2017). The seven deadly sins of world university ranking: a summary from several papers. Journal of Higher Education Policy and Management, Volume 39, Issue 1, pp. 104-115.

20.Soh, K. (2015). What the Overall doesn't tell about world university rankings: examples from ARWU, QSWUR, and THEWUR in 2013. Journal of Higher Education Policy and Management, Volume 37, Issue 3, 295-307.

21.Sombatsompop, N., Premkamolnetr, N., Markpin, T., Ittiritmeechai, S., Wongkaew, C., Yochai, W., Ratchatahirun, P., Beng, L.I. (2011). Viewpoints on synergising ASEAN academic visibilities through research collaboration and the establishment of an ASEAN Citation Index Database. Asia Pacific Viewpoint, Volume 52, Issue 2, pp. 207-218.

22.Sorz, J., Wallner, B., Seidler, H. Fieder, M. (2015). Inconsistent year-to-year fluctuations limit the conclusiveness of global higher education rankings for university management. PeerJ, Volume 8, Article number 1217.

23. Tutterow, C., Evans, J.A. (2016). Reconciling the small effect of rankings on university performance with the transformational cost of conformity. Research in the Sociology of Organizations, Volume 46, pp. 265-301.

24. Uslu, B. (2017). The influence of organisational features in high-ranked universities: the case of Australia. Journal of Higher Education Policy and Management, Volume 39, Issue 5, pp. 471-486.

25. Wæraas, A., Solbakk, M.N. (2009). Defining the essence of a university: Lessons from higher education branding. Higher Education, Volume 57, Issue 4, pp. 449-462.

26. Williams, R., Van Dyke, N. (2007). Measuring the international standing of universities with an application to Australian universities. Higher Education, Volume 53, Issue 6, pp. 819-841.

27. Williams, R., Van Dyke, N. (2008). Reputation and reality: Ranking major disciplines in Australian universities. Higher Education, Volume 56, Issue 1, pp. 1-28. 